\title{
Marxist Theory of Liberty and Its Contemporary Value
}

\author{
Zemin Zhang \\ School of Literature, Law and Economics \\ Wuhan University of Science and Technology \\ Wuhan, China
}

\begin{abstract}
Since ancient times, liberty is the foundation of human activities. Therefore, in a sense, the historical development of mankind from ancient times to the present is the entire process of mankind's pursuit of liberty. The establishment and development of historical materialism has always been in opposition to equality, democracy, and liberty discussed by the bourgeoisie. It is precisely on the basis of historical materialism that Marx revolutionized the view of liberty of the bourgeoisie and proposed the theory of liberty that belongs to itself and socialism. Liberty is the core value of socialism with Chinese characteristics. A profound analysis of the Marxist theory of liberty is of great value to the construction of China's socialist ideology and the full realization of socialist freedom. Based on this, this paper analyzes the formation, connotation and basic characteristics of Marxist theory of liberty, and explores its value to social development in China.
\end{abstract}

\section{Keywords-Marxism; theory of liberty; value}

\section{THE GENERATION OF MARXIST THEORY OF LIBERTY}

The formation of any ideas and thoughts must undergo a process of budding, development, and maturity. Marxist theory of liberty is no exception. Among many influencing factors, the cultural thoughts generated by social background and social background are undoubtedly the core that influence the ideas. The creation of Marxist theory of liberty is based on the practical experience of the proletarian workers' movement. Specifically, the generation of Marxist theory of liberty can be roughly divided into several stages.

\section{A. The First Stage-Budding}

In his graduation thesis for middle school "The Youth's Consideration in Choosing a Career", Marx pointed out: "If we make human welfare the first criterion of our choice of profession, any pressure from any profession will not overwhelm us, because our labor achievements will benefit millions of people, our cause will last forever, and our spirit will be circulated forever, without feeling humble, pitiful, and selfish [1]. Marx believes that young people should choose noble professions, and nobleness refers to being able to benefit others, society, and even dedication to society. This is the spiritual thought of Marx in his youth period, which laid the foundation for his theory of liberty. During the university, Marx praised Hegel's philosophy under the social background covered by Hegel's philosophy and even chose to turn from the law major to the philosophy major. His doctoral dissertation "The Natural Philosophy of Demo Crete and the Difference of Natural Philosophy of Epicurus" makes profound analysis of human free spirit based on Epicurus's "deflection theory". For liberty, Epicurus proposes that "only if the individual's consciousness leaves the world, is it true liberty [2]." Marx thinks that Epicurus' view of liberty exists with nothingness, negativity, emptyness, and unreality, but the "view of liberty" in the real sense should be full of strength, contact with reality, and exist in the real existence of human beings. In this stage, Marx placed the focus on reality, but at this time his understanding of the nature of liberty remains unclear.

\section{B. The Second Stage-Development}

After graduating from college, Marx worked in the Rheinische Zeitung. At this time, Marx was full of yearning for liberty, and he wanted liberty, especially the liberty of press related to his work. In the course of the work in the Rheinische Zeitung, Marx published a "Comment on Prussian Book Inspection Order" in dissatisfaction with the government's book inspection order and criticized the problems in the government's book inspection order. "I love to use humorous statement to describe things, but the law requires me to use a serious tone; I love to use passionate language, but the law requires me to use humble style [3]." This is the first critical article published by Marx. In the ensuing period of time, Marx also published articles such as Debates on Freedom of the Press and the Defence of the Moser Reporter, to criticize the aristocrats against liberty and reveal the essence of liberty. [4]With the closure of The Rheinische Zeitung, Marx challenged Hegel's philosophy, arguing that Hegel's liberty does not exist in current society and is not realistic. Subsequently, he published a series of critical articles such as "Critique of Hegel's Philosophy" "On the Jewish Question," and "1844 Economic and Philosophical Manuscripts" [5]. In this stage, Marxist theory of liberty has not yet been fully formed, and there is no essential difference with utopian socialism and humanism.

\section{The Third Stage-Maturity}

Following the "1844 Manuscript of Economic Philosophy", the mark that represents the complete formation of Marxist theory of liberty was the "German 
Ideology". In this book, Marx profoundly reveals the relationship between human nature and social practice. Based on historical materialism, Marx puts forward the combination of liberty and objective life and the development of human's comprehensive and free thinking. In this stage, Marx's concept of freedom was completely formed and was continuously improved in the following period of time.

\section{THE CONNOTATION AND BASIC CHARACTERISTICS OF MARX'S THEORY OF LIBERTY}

\section{A. The Connotation of Marxist Theory of Liberty}

Marxist theory of liberty has a rich theoretical basis and its connotation is relatively large. In summary, it can be divided into three points. First, practice is the foundation of freedom. Marxist theory of liberty is based on realistic issues. Under this conception, the emergence and development of liberty must follow the practice of human beings, which is "the materialization of the self-fulfilling subject as well as the actual liberty that can be seen in labor precisely." [6] Under Marxist theory of liberty, liberty must be embodied in human activities, and must also be the result of practice. "When people want to be free, they usually do it according to their own conditions or within a range that they can quickly implement, rather than their own ideals or even their own ideal of the future [7]. Second, liberty is not subjective and arbitrary. It must be dialectically combined with necessity. The Anti-Duhring Theory pointed out: "Freedom is not obtained through illusion to get rid of the bondage on one's body, but on the basis of knowing the bondage and understanding the bondage, using the bondage to create freedom for oneself. Liberty is achieved through the understanding of the necessity existing in nature [8]. "Only by constantly breaking through our understanding of nature and the necessity of nature, human beings can break free from the constraints that they bring to humanity, and then realize real liberty." Third, it realizes the free and comprehensive development of human beings. Marxist theory of liberty regards the realization of the free liberation of human freedom as the ultimate goal. Marx's "Manuscript of Economics in 1857-1858" analyzed the three forms that human experienced, mainly including dependence, independence, and liberty. These three different forms are mainly based on the degree of human liberty. In the first form, human beings are completely bound by nature or others and lose their liberty and independence completely; in the second form, people enter the capitalist society, and then to a certain extent, they have independence and liberty, but they are still constrained by ruling class in the capitalist economic system. The third form is the supreme form of Marxist theory of liberty, which has only existed in the illusion of Marxism till now, namely a fully emancipatory and independent communist society. People share all resources in society together and free, comprehensive development of mankind is realized and the true essence of liberty can be achieved.

\section{B. The Basic Characteristics of Marxist Theory of Liberty}

1) Free class regularity: Class is the group with different status existing in the social structure. There are often irreconcilable contradictions and conflicts between different classes. Marx used the contradictions and conflicts between different classes as the methods and principles for studying liberty. In the class society, the lower classes must follow the instructions of the upper class, and liberty is that in class relations. Therefore, the class nature of liberty is the main component of Marxist theory of liberty.

2) The historical specificity of liberty: The historical specificity is taking the specific events in the historical process as the theory and method of studying liberty. Marx believes that liberty doesn't exist in the "conscious world" in nothingness and empty but exists in the real world and is a product of the historical development. Once liberty lacks historical specificity, it becomes an empty and abstract form and loses the essential value of liberty itself.

3) Practical structure of liberty: Practical structure is that people change the behavior of an object through some means and methods. Marx puts it: "Practice is the essence of human social life. Any mystical interpretation of theory can be found in the human social life practice [9]." He thinks that if it only liberates people from illusory theology and does not go further in practice, it cannot be called liberty." The relationship is like the reform of agriculture to serfdom, and the steam engine to slavery. Therefore, Marx's thought of practical structure is the core of his view of liberty.

4) Social reality of liberty:

Social reality is the life regularity of human in human society. Human beings are the basic unit of society. "The relationship that is generated in human's production in society is the social production relationship. Social production relationship will change with changes in productivity and means of production. The combination of different social production relations is the social relationship, and social relationship consist society. This society has different characteristics in different stages of human production. Ancient societies, feudal societies, and capitalist societies were all different stages of the development of social relations. This social stage created by social production relationship marked a number of different special stages in human history [10]." In Marx's view, the reality of social relations is an inevitable prerequisite for liberty to emerge.

\section{THE CONTEMPORARY VALUE OF MARXIST THEORY OF LIBERTY}

\section{A. Facilitating the Development of Socialist Democratic Politics with Chinese Characteristics}

In the ancient period of feudalism, the people were oppressed by ruling class, and the entire society was full of inequality and illiberality. Only a very small number of people could have an influence on the national politics through formal channels. Until now, people have become the rulers of the country. As a typical representative of socialist 
countries, liberty and equality are its core values. People's active participation in political decision-making is a direct expression of Marxist theory of liberty. The Nineteenth Congress proposed to insist that people should be the masters of the country, persist in taking the people as the center, persist in the harmonious coexistence of man and nature, and adhere to the principle of comprehensive and legal governance. These are the direct manifestations of the participation of the whole people in politics [11]. In a country where all the people participate in politics, there must be a strong atmosphere of liberty. Only in this way can the democratic politics of socialism with Chinese characteristics develop orderly in a free environment.

\section{B. Facilitating the Development of a Socialist Market Economy with Chinese Characteristics}

Competition is the core of the socialist market economy. Only if there is competition, can the socialist market economy be operated stably and its economic system can run healthily. In this regard, Marxist theory of liberty can effectively achieve this goal. First is liberty of competition under Marxist theory of liberty. We should enhance the enthusiasm of enterprises and encourage them to participate in market competition, in order to stimulate their potential. Under the scientific competition mechanism, the realization of the basic principle of survival of the fittest can promote the development of the socialist market economy. Second is the freedom to enter the market under the Marxist theory of liberty. At present, there are more or less barriers to the entry of similar products in the socialist market in China. To achieve freedom of competition of the market, it is a prerequisite to reduce or even remove barriers to entry of similar products. Only in this way can similar products continue to break out from the competition, continue to improve, and continue to complete. The key to achieving this ultimate goal lies in upholding Marxist theory of liberty.

\section{Helping to Promote the Progress of Social Material Civilization and Spiritual Civilization}

If we study the principle in ancient times, it is not difficult to discover that the material and spiritual civilization of human society has been continuously improving. The progress of civilization is an inevitable trend of comprehensive growth and popularization of economy and culture. The development of both material civilization and spiritual civilization will inevitably fail to leave the specific object of "human". Human is the core of promoting the continuous progress of material civilization and spiritual civilization, such as the opening up of new routes, and industrial and agricultural reforms, and so on. It is freedom that promotes the constant progress of human civilization. People's desire for freedom is precisely the desire for liberty, which promote the constant development of human beings. At present, China is at the primary stage of socialism with Chinese characteristics, so there is still a long way to go. Only under the guidance of Marxist theory of liberty, can the material and spiritual civilization of China develop continuously and effectively and achieve progress.

\section{CONCLUSION}

Pursuit of liberty is the fundamental driving force for human activities and the significance of social development. Marxist theory of liberty is based on the "human" existing in the real society. It takes the realization of the "liberty" of the "human" as the ultimate goal. It points out that human liberty comes from the human's own life practice and results in human practice. That is, the realistic practice of human beings is the root for the existence and manifestation of liberty. For Marx, liberty does not exist in illusion, but can be directly reflected in the historical development of human beings, which can continuously develop and enrich. It is a process of dialectical negation. In this process, people continuously seek for the value of life and the meaning of life in pursuit of liberty. For more than a hundred years, bourgeois thinkers have been arbitrarily distorting and slandering Marxist theory of liberty in an attempt to reduce or even eliminate the influence of Marx's thoughts on them, but it was ineffective. This stems from the profound implication of Marxist theory of liberty and its help to the development of socialism.

\section{REFERENCES}

[1] Lin Jian. Reinterpretation of Marx's View of Freedom[J]. Tianjin Social Sciences, 2003(6):32-35. 林剑.马克思自由观的再解读 [J].天 津社会科学, 2003(6):32-35.

[2] Zhang Wenxi. On the Contemporary Vision of Marxist Theory of Liberty [J]. Academic Monthly, 2006(8):42-47. 张文喜. 论马克思自 由观的当代视野 [J].学术月刊,2006(8):42-47.

[3] Zhang Sanyuan. On Marx's Three Forms of Liberty-One of the Researches on Marxist Theory of Liberty[J]. Academics in China, 2012(1):60-72. 张三元. 论马克思关于自由的三种形态一一马克思 自由观研究之一[J].学术界,2012(1):60-72.

[4] Yang Lizhen. Interpretation of Marxist Theory of Liberty in the German Ideology [J]. Socialism Studies, 2009(1): 24-27. 杨丽珍. 《德意志意识形态》中的马克思自由观阐释 [J].社会主义研 究,2009(1):24-27.

[5] Hou Xiaofeng. Realistic orientation of Epicurean Philosophy and the Foundation of Marxist Theory of Liberty_rereading Marx's Doctoral Thesis[J]. Dongyue Tribune, 2012,33(12):53-59. 侯小丰.伊 壁鸭鲁哲学的现实指向与马克思自由观的奠基——重读马克思博 士论文[J].东岳论丛,2012,33(12):53-59.

[6] Xia Ying. Liberty and History: A Comparative Study of Hegel's and Marxist Theory of Liberty: A Survey Based on Karl Popper's Criticism[J]. Jilin University Journal Social Sciences Edition, 2015(2): 155 -161. 夏莹.自由与历史:黑格尔与马克思自由观之比较一一以 卡尔・波普尔的批判为视角的一种考察 [J]. 吉林大学社会科学学 报,2015(2):155-161.

[7] Zhong Minghua, Liu Zhuohong. The Continuity and Phase of the Development of Marxist Theory of Liberty: A Comparative Study of the View of Liberty in Marx's Two Manuscripts[J]. Social Sciences Guangdong, 1991(3):49-54. 钟明华,刘卓红.马克思自由观发展的连 续性和阶段性一一马克思两部《手稿》中的自由观比较研究 $[\mathrm{J}]$. 广东社会科学,1991(3):49-54.

[8] Huang Jifeng, Li Jing. On Walitsky's Construction of Marxist Theory of Liberty[J]. Shandong Social Sciences, 2017(8):42-47. 黄继锋,李晶. 论瓦利茨基对马克思自由观的构建 [J]. 山东社会科学,2017(8):4247.

[9] Tu Liangchuan, Li Ailong. The dual orientation and realistic implication of Marxist Theory of Liberty[J]. Shandong Social Sciences, 2017(6):25-30. 涂良川,李爱龙.马克思自由观的双重向度 及现实意蕴 $[J]$.山东社会科学,2017(6):25-30 
[10] Li Zhiqiang. On the Ecological Implication of Marxist Theory of Liberty[J]. Philosophical Researches, 2014(6):16-20. 李志强. 论马克 思自由观的生态意蕴[J].哲学研究,2014(6):16-20.

[11] Bao Jin. How to be free: The reinterpretation of Marxist Theory of Liberty[J]. Tianjin Social Sciences, 2016(5):45-51. 鲍金. 自由何以可 能:马克思自由观的再阐释 [J].天津社会科学,2016(5):45-51. 